\title{
Effect of Fenarimol Application Timing on Fruit Shape of Bartlett Pear
}

David Sugar, Oregon State University, Southern Oregon Research and Extension Center, Medford 97502; R. A. Spotts, Oregon State University, Mid-Columbia Agricultural Research and Extension Center, Hood River 97031; W. D. Gubler, University of California, Department of Plant Pathology, Davis 95616; and Glenn T. McGourty, University of California, Mendocino County Cooperative Extension Service, Ukiah 95482

\begin{abstract}
Sugar, D., Spotts, R. A., Gubler, W. D., and McGourty, G. T. 2000. Effect of fenarimol application timing on fruit shape of Bartlett pear. Plant Dis. 84:182-184.

Plots were established at Ukiah and Davis, California, and Medford and Hood River, Oregon, to evaluate the effect of fenarimol (Rubigan 1 EC), applied at various stages of bloom development, on fruit shape of Bartlett pear. At each location, 10 different treatment schedules were applied at various combinations of bud burst (BB), green cluster (GC), white bud (WB), and full bloom (FB). In schedules that included an application at FB, the fruit length:diameter (L/D) ratio was significantly reduced in at least three of four locations when compared to untreated controls. When fenarimol was applied at $\mathrm{BB}, \mathrm{GC}, \mathrm{WB}$, and $\mathrm{FB}$, the $\mathrm{L} / \mathrm{D}$ ratio was reduced at all locations. Treatment at BB only did not affect $\mathrm{L} / \mathrm{D}$ ratio. Schedules involving GC or WB, but not $\mathrm{FB}$, resulted in reduced L/D ratios at only one or two locations. When data from all four locations were combined, L/D ratios were significantly reduced by all fenarimol treatments except $\mathrm{BB}$ alone, and the smallest L/D ratios resulted from treatments which included applications at both WB and FB. Fruit stem length was significantly reduced by all timings of fenarimol application except GC at Medford, and all timings except BB and GC at Ukiah. Fruit weight did not differ among treatments.
\end{abstract}

Additional keywords: pyrimidine fungicides, Pyrus communis

Fenarimol (2-chlorophenyl-4-chlorophenyl-5-pyrimidinemethanol (Elanco Products Co., Indianapolis, IN; currently Dow Agrosciences, Inc.) was registered as the active ingredient in Rubigan 1 EC for control of pear scab in the United States in 1987. It is a fungicide of the pyrimidine class, and is known to inhibit synthesis of ergosterol and consequently affect membrane function in sensitive fungi (8).

A relatively elongated fruit shape is considered esthetically most desirable in marketing cv. Bartlett pears for fresh consumption, and is preferred by canneries for optimum functioning of peeling machinery. In 1992, some growers and researchers observed fruit with a flatter shape than normal on Bartlett pear trees (Pyrus communis L.) and considered the possible association of this appearance with applications of fenarimol. In the following year, plots were established in four pear-growing areas to evaluate a series of fenarimol ap-

Corresponding author: D. Sugar

E-mail: David.Sugar@orst.edu

Oregon Agricultural Experiment Station technical paper 11,567.

Accepted for publication 10 November 1999.

Publication no. D-1999-1217-02R

(C) 2000 The American Phytopathological Society plication programs for their effect on fruit shape.

\section{MATERIALS AND METHODS}

At each of four locations (Ukiah and Davis, California, and Medford and Hood River, Oregon), plots were established in blocks of cv. Bartlett pear trees in 1993. Treatments and an untreated control were arrayed in a randomized complete block design, with each treatment consisting of four replicate units, each containing two adjacent trees, except that at Davis each treatment consisted of three single-tree replicates. Fenarimol (as Rubigan 1 EC) was applied by hand-gun sprayers at the rate of $731.4 \mathrm{ml} / \mathrm{ha}$, with 935.3 liters of solution applied per hectare. Treatments were applied at various combinations of four stages of flower bud development: bud burst (BB), green cluster (GC), white bud (WB), and full bloom (FB). Dates of bud development and, consequently, of treatment applications varied among the four locations (Table 1). Trees used in the experiment were 39, 14, 25, and 19 years old at Ukiah, Davis, Medford, and Hood River, respectively.

At maturity, 25 fruit in a zone 1 to $2 \mathrm{~m}$ above ground were randomly harvested from each replicate. The length (stem insertion to calyx) and widest transverse diameter of the harvested fruit were measured, and fruit shape was expressed at the ratio of length to diameter (L/D). At Ukiah and Medford, stem length and fruit weight were also measured on the sampled fruit.

\section{RESULTS}

At all timings which included an application at FB, fruit L/D ratio was significantly reduced in at least three of four locations as compared to the untreated control (Table 2). When fenarimol was applied at BB, GC, WB, and FB, the L/D ratio was reduced at all locations. The average reduction in L/D ratio resulting from the four fenarimol applications was 10.4, 11.4, 11.7, and 7.5\% at Ukiah, Davis, Medford, and Hood River, respectively. Fruit from trees receiving four applications of fenarimol had the numerically smallest L/D ratio at Davis and Hood River, whereas the $\mathrm{L} / \mathrm{D}$ ratio resulting from treatment at GC, WB, and FB was numerically smallest at Ukiah and Medford. Treatment at BB only did not affect L/D ratio. Treatments involving GC or WB, but not $\mathrm{FB}$, resulted in reduced $\mathrm{L} / \mathrm{D}$ ratios at only one or two locations. When data from all four locations were combined, L/D ratios were significantly $(P<0.05)$ reduced by all fenarimol treatments except $\mathrm{BB}$ alone, and the smallest L/D ratios resulted from treatments which included applications at both WB and FB (Table 2).

Fruit stem length was significantly reduced by all timings of fenarimol application except $\mathrm{BB}$ and $\mathrm{GC}$ at Ukiah, and all timings except GC at Medford (Table 3). The maximum stem length reduction was $20.9 \%$ at Ukiah and $25.8 \%$ at Medford. Average fruit weight was not significantly

Table 1. Pear bud development stages and fenarimol application dates at four locations in 1993

\begin{tabular}{lrrrr}
\hline & \multicolumn{3}{c}{ Application dates } \\
\cline { 2 - 5 } Stages & Ukiah & Davis & Medford & Hood River \\
\hline Bud burst (BB) & 7 March & 8 March & 15 March & 2 April \\
Green cluster (GC) & 11 March & 13 March & 22 March & 16 April \\
White bud (WB) & 15 March & 17 March & 29 March & 21 April \\
Full bloom (FB) & 19 March & 22 March & 7 April & 27 April \\
\hline
\end{tabular}


different among treatments at the two locations where this was measured.

\section{DISCUSSION}

Although the effect of specific fenarimol treatment timings on L/D ratios varied among locations, reduction in $\mathrm{L} / \mathrm{D}$ ratio was most strongly associated with treatment timings that included WB and FB. These results support the change in the Rubigan product label after 1993 to prohibit application prior to petal-fall. Treatment early in flower-bud development (BB) had no effect on fruit L/D ratio, and the authors have subsequently observed no apparent fruit-shape effects resulting from fenarimol applications at petal-fall or later.

Gibberellins are involved in cell enlargement during fruit growth (3). Externally applied gibberellic acid (GA) tends to promote elongated fruit (increase L/D ratios) in apple $(14,16,18)$ and pear (4). Used on pear, GA sprays may induce excessive elongation, considered undesirable in commerce (15). Treatment with inhibitors of gibberellin synthesis, such as N-dimethylaminosuccinamic acid (Alar) and related compounds, may result in relatively flattened apples (13) or pears (7). Sisler (9) suggested that the effects of fenarimol and some other ergosterol biosynthesis inhibitors (EBIs) on plant growth may involve the shared dependence of ergosterol and GA biosyntheses on cytochrome P-450. External application of GA also has been associated with an increase in apple stem length (17). In our study, most fenarimol applications resulted in reduced stem length. Spotts and Cervantes (10) found no effects on L/D ratios in fruit of cv. Newtown apple treated with the EBI fungicides triadimefon or etaconazole.

Other factors, including temperature immediately following bloom, crop density, and rootstock, can also affect fruit shape $(3,12,17)$. Cool temperatures immediately following bloom tend to promote elongated fruit shape, whereas warm temperatures during this period promote flatter fruit $(3,17)$. The $\mathrm{L} / \mathrm{D}$ ratio of pear fruit tends to be greatest soon after fruit set, and fruit shape gradually flattens during the course of fruit enlargement until about 100 days after bloom (14). The L/D ratios of mature $\mathrm{cv}$. Bartlett pears from commercial orchards in several growing districts in California, Oregon, and Washington measured in 1931 showed a trend towards longer fruit with increasing northern latitude (12).

Reduced yield was reported on apple trees receiving 24 applications of fenarimol over a 3-year period, as compared to trees on which powdery mildew was controlled with a non-EBI fungicide, binapacryl (5). Fewer apples rather than lower individual fruit weight accounted for the yield reduction. In contrast, Strydom and Honeyborne (11) observed increased fruit set in apple trees treated with fenarimol. In the present study, although fruit set and yield were not measured, we found that fenarimol applications did not affect fruit weight of $\mathrm{cv}$. Bartlett pear.

Triazole and pyrimidine fungicides have been associated with incidence of smaller, thicker, darker green leaves in apple (2). EBIs with this "triazole effect" can also improve fruit set (2). We did not observe foliar abnormalities following early-season treatments in the present study. Some EBIs suppressed following-year bloom on apple cvs. Redspur Delicious and McIntosh following season-long applications during the previous season $(1,6)$.
Non-target effects of fungicide treatments on host characteristics deserve attention in the evaluation of fungicides for disease management. In this case, applications of a fungicide at timings which might be efficacious in disease control affected fruit shape, with potential consequences to the market desirability of the fruit

\section{ACKNOWLEDGMENTS}

Elanco Products Co. (currently Dow Agrosciences, Inc.) provided financial support for this research.

\section{LITERATURE CITED}

1. Biggs, A. R. 1990. Reduction in transpiration and return bloom in apple by two sterol-inhibiting fungicides. HortScience 25:14031405.

2. Creemers, P., and Vanmechelen, A. 1993. Side effects of fungicides on pome fruit. Meded. Fac. Landbouwwet. Rijksuniv. Gent. 58:1421-1429.

3. Faust, M. 1989. Physiology of Temperate Zone Fruit Trees. John Wiley \& Sons, New York

4. Griggs, W. H., and Iwakiri, B. T. 1961. Effect of gibberellin and 2,4,5-trichlorophenoxypropionic acid sprays on Bartlett pear trees. Proc. Am. Soc. Hortic. Sci. 77:73-89.

5. Hutcheon, J. A., Coyle, J., Holgate, M. E., and Byrde, R. J. W. 1986. Effects of fungicides on long-term cropping and fruit quality of apple. Plant Pathol. 35:249-253.

6. Latham, A. J., Dozier, W. A., Knowles, J. W. and Hollingsworth, M. H. 1985. Suppression of apple bloom by fungicides that inhibit sterol synthesis. Plant Dis. Rep. 69:776-778.

7. Modlibowska, I., and Wickenden, M. F. 1977.

Table 3. Effect of timing of application of fenarimol to cv. Bartlett pear trees on the stem length and weight of harvested fruit ${ }^{y}$

\begin{tabular}{llllcc}
\hline & \multicolumn{2}{c}{ Mean stem length $(\mathbf{m m})$} & & \multicolumn{2}{c}{ Mean fruit weight $(\mathbf{g})$} \\
\cline { 2 - 3 } \cline { 5 - 6 } Application timing $^{\mathbf{z}}$ & Ukiah & Medford & & Ukiah & Medford \\
\hline BB & $26.5 \mathrm{a}$ & $22.6 \mathrm{bc}$ & & 155 & 154 \\
BB, GC & $23.4 \mathrm{~cd}$ & $21.3 \mathrm{bcd}$ & & 154 & 145 \\
BB, GC, WB & $21.9 \mathrm{def}$ & $20.5 \mathrm{cde}$ & & 164 & 145 \\
BB, GC, WB, FB & $20.0 \mathrm{~g}$ & $19.7 \mathrm{de}$ & & 163 & 156 \\
GC & $24.1 \mathrm{bc}$ & $23.1 \mathrm{ab}$ & & 157 & 160 \\
GC, WB & $21.5 \mathrm{efg}$ & $21.5 \mathrm{bcd}$ & & 164 & 149 \\
GC, WB, FB & $20.9 \mathrm{fg}$ & $18.7 \mathrm{e}$ & & 164 & 145 \\
WB & $22.6 \mathrm{cdef}$ & $22.2 \mathrm{bc}$ & & 161 & 139 \\
WB, FB & $21.6 \mathrm{efg}$ & $21.9 \mathrm{bcd}$ & & 163 & 147 \\
FB & $23.0 \mathrm{cdef}$ & $22.1 \mathrm{bc}$ & & 158 & 153 \\
Untreated & $25.3 \mathrm{ab}$ & $25.2 \mathrm{a}$ & & 150 & 158 \\
\hline
\end{tabular}

y Values in each column followed by the same letter are not significantly different according to Duncan's new multiple range test $(P=0.05)$.

${ }^{\mathrm{z}} \mathrm{BB}=$ bud burst, $\mathrm{GC}=$ green cluster, $\mathrm{WB}=$ white bud, and $\mathrm{FB}=$ full bloom.

Table 2. Effect of timing of application of fenarimol to cv. Bartlett pear trees on the length:diameter ratio of harvested fruit ${ }^{y}$

\begin{tabular}{|c|c|c|c|c|c|}
\hline Application timing ${ }^{\mathrm{z}}$ & Ukiah & Davis & Medford & Hood River & Mean of four locations \\
\hline BB & $1.27 \mathrm{a}$ & $1.21 \mathrm{ab}$ & $1.17 \mathrm{a}$ & $1.32 \mathrm{abc}$ & $1.24 \mathrm{a}$ \\
\hline $\mathrm{BB}, \mathrm{GC}$ & $1.23 \mathrm{abc}$ & $1.17 \mathrm{abc}$ & $1.11 \mathrm{bc}$ & $1.31 \mathrm{abc}$ & $1.21 \mathrm{~b}$ \\
\hline $\mathrm{BB}, \mathrm{GC}, \mathrm{WB}$ & $1.18 \mathrm{~cd}$ & $1.13 \mathrm{abc}$ & $1.07 \mathrm{bcd}$ & $1.30 \mathrm{abcd}$ & $1.17 \mathrm{~b}$ \\
\hline $\mathrm{BB}, \mathrm{GC}, \mathrm{WB}, \mathrm{FB}$ & $1.12 \mathrm{e}$ & $1.09 \mathrm{c}$ & $1.06 \mathrm{~cd}$ & $1.24 \mathrm{~d}$ & $1.13 \mathrm{c}$ \\
\hline GC & $1.22 \mathrm{bc}$ & $1.13 \mathrm{abc}$ & $1.12 \mathrm{~b}$ & $1.29 \mathrm{abcd}$ & $1.19 \mathrm{~b}$ \\
\hline $\mathrm{GC}, \mathrm{WB}$ & $1.14 \mathrm{de}$ & $1.14 \mathrm{abc}$ & $1.10 b c$ & $1.29 \mathrm{abcd}$ & $1.17 \mathrm{~b}$ \\
\hline GC, WB, FB & $1.10 \mathrm{e}$ & $1.13 \mathrm{abc}$ & $1.04 \mathrm{~d}$ & $1.26 \mathrm{~cd}$ & $1.13 \mathrm{c}$ \\
\hline WB & $1.19 \mathrm{c}$ & $1.14 \mathrm{abc}$ & $1.11 \mathrm{bc}$ & $1.34 \mathrm{ab}$ & $1.20 \mathrm{~b}$ \\
\hline WB, FB & $1.13 \mathrm{e}$ & $1.14 \mathrm{abc}$ & $1.05 \mathrm{~d}$ & $1.25 \mathrm{~d}$ & $1.14 \mathrm{c}$ \\
\hline FB & $1.21 \mathrm{bc}$ & $1.11 \mathrm{bc}$ & $1.09 \mathrm{bcd}$ & $1.27 \mathrm{bcd}$ & $1.17 \mathrm{~b}$ \\
\hline Untreated & $1.25 \mathrm{ab}$ & $1.23 \mathrm{a}$ & $1.20 \mathrm{a}$ & $1.34 \mathrm{a}$ & $1.26 \mathrm{a}$ \\
\hline
\end{tabular}

y Values in each column followed by the same letter are not significantly different according to Duncan's new multiple range test $(P=0.05)$.

${ }^{\mathrm{z}} \mathrm{BB}=$ bud burst, $\mathrm{GC}=$ green cluster, $\mathrm{WB}=$ white bud, and $\mathrm{FB}=$ full bloom. 
The effect of hormones on growth and cropping of pears. Acta Hortic. 69:191-200.

8. Siegel, M. R. 1981. Sterol inhibiting fungicides: effects on sterol biosynthesis and sites of action. Plant Dis. 65:986-989.

9. Sisler, H. D., Ragsdale, N. N., and Waterfield, W. F. 1984. Biochemical aspects of the fungitoxic and growth regulatory action of fenarimol and other pyrimidin-5-ylmethanols. Pestic. Sci. 15:167-176.

10. Spotts, R. A., and Cervantes, L. A. 1986. Effects of fungicides that inhibit ergosterol biosynthesis on apple powdery mildew control, yield, and fruit growth factors. Plant Dis. 70:305-306.
11. Strydom, D. K., and Honeyborne, G. E. 1983. Increase in fruit set of 'Starking Delicious' apple with fenarimol. Deciduous Fruit Grower Sagtevrugteboer 33:246-247.

12. Tufts, W. P., and Hansen, C. J. 1931. Variation in shape of Bartlett pears. Proc. Am. Soc. Hortic. Sci. 28:627-633.

13. Webster, D. H., and Crowe, A. D. 1969. Effects of gibberellic acid, N-dimethylaminosuccinamic acid (Alar), ringing and thinning on McIntosh apple shape. J. Am. Soc. Hortic. Sci. 94:308-310.

14. Westwood, M. N. 1962. Seasonal changes in specific gravity and shape of apple, pear, and peach fruits. Proc. Am. Soc. Hortic. Sci.
80:90-96.

15. Westwood, M. N. 1993. Temperate-Zone Pomology: Physiology and Culture. 3rd Ed. Timber Press, Portland, OR.

16. Westwood, M. N., and Bjornstad, H. O. 1968. Effects of gibberellin $\mathrm{A}_{3}$ on fruit shape and subsequent seed dormancy of apple. HortScience 3:19-20.

17. Westwood, M. N., and Blaney, L. T. 1963. Non-climatic factors affecting the shape of apple fruits. Nature 200:802-803.

18. Williams, M. W., and Stahly, E. A. 1969. Effect of cytokinins and gibberellins on shape of 'Delicious' apple fruits. J. Am. Soc. Hortic. Sci. 94:17-19. 